\title{
Assessment of Customers' Satisfaction with E-Banking System in the North-Eastern Region of Nigeria
}

\author{
K. Biradawa $\mathrm{PhD}$ \\ Department of Banking and Finance, University of Maiduguri, P.M.B. 1069, Maiduguri, Borno State, Nigeria
}

\begin{abstract}
This study assessed customers' satisfaction with electronic banking system in some selected commercial banks in the North-Eastern region of Nigeria. The study utilized primary data gathered through administration of questionnaires on customers of three (3) commercial banks across the six (6) states of the North-East. A total of four hundred and fifty (450) customers were selected as sample. That is, twenty-five (25) respondents from each of the three (3) banks in a state (i.e. making 75 in a state) were chosen which made up the total of four hundred and fifty (450). Convenience and purposive non-probability sampling techniques were used in selecting the banks and customers respectively. Descriptive and inferential statistics were applied to analyse the data. The results revealed that customers' satisfaction with e-banking system in the North-Eastern region of Nigeria is strong, positive and statistically significant. This is affirmed by the r-values of $0.752,0.901,1.000,0.637,0.637$ and 0.641 for the respective e-banking satisfaction proxies. The p-values of 0.000 for all the six (6) proxies equally affirmed that customers' satisfaction with e-banking system is statistically significant at 5\%, and even $1 \%$ levels of significance. Though the study disclosed statistically significant customers' satisfaction with e-banking system, the strength of the satisfaction varies among the e-banking satisfaction proxies especially, transaction cost, transaction time and reliability yield higher levels than ease of use, convenience and security/privacy. The study therefore, suggests that commercial banks should improve on ease of use, convenience and security/privacy of the e-banking system which it is hoped might further enhance customers' satisfaction with the system.
\end{abstract}

Keywords: Electronic banking, Customers' satisfaction, Commercial banks, North-east Nigeria.

DOI: $10.7176 / \mathrm{EJBM} / 11-23-01$

Publication date: August $31^{\text {st }} 2019$

\section{Introduction}

The introduction and adoption of Information and Communication Technology (ICT) by the banking industry in the $21^{\text {st }}$ century has globally changed the face of commercial banking from traditional (or manual) system to electronic system of banking. The hitherto traditional system used to involve posting of transactions from one ledger to another, counting of money, making payments, account balance inquiry, and many other forms of transaction by the bank employees themselves and usually in designated banking halls. This system, according to Akinglola (2006) was prone to inaccuracies largely due to human errors. He also considers it to be characterized by slow pace of transactions, tediousness, avalanche of paper work, sluggishness and undue waste of time spent by customers in banking halls.

However, with the adoption of ICT by most banks in recent times, banking operations rapidly changed from manual to electronic systems. Electronic system of banking generally referred to as e-banking involves the use of networks and internet for delivering of bank products and services. It encompasses the processes by which customers may carry out banking activities electronically without necessarily having to go to a banking hall (Simon $\&$ Thomas, 2016). This suggests that unlike the traditional system which requires banks customers and staff to interact on a face-to-face basis for a transaction to be carried out, the electronic system allows customers to perform their banking transactions without the need for physical face-to face interaction with bank staff.

The electronic system is said to have provided many solutions to most of the difficulties inherent in the traditional method (Idowu, 2005). According to him, the e-system has created more convenient ways of performing banking business by yielding easier, faster, quality and reliable services with great reduction in customer time spent in accessing bank products or services. Thus, one of the cardinal objectives for adopting e-banking by commercial banks is to provide customers with uninterrupted, reliable and convenient bank services in order to satisfy and retain customers.

However, in spite of the adoption of e-banking by commercial banks and its intended benefits, customers' satisfaction with the system is said to be influenced by a number of variables. Such variables, according to Jham (2016) include transaction time, accuracy of transactions, transaction cost, reliability, ease of use and security/privacy. It is therefore, against this background that this study seeks to evaluate customers' satisfaction with electronic banking system in the North-East of Nigeria.

\section{Hypothesis}

This study is guided by a hypothesis formulated and tested at 5\% level of significance.

Ho: Customers' satisfaction with e-banking system in North-Eastern Nigeria is not statistically significant. 


\section{Conceptual Review}

There is no universally accepted definition for the term electronic banking because it tends to vary among scholars. The term is technically and intricately complex largely because it encompasses several forms of services through which banks and their customers may access information and carry out business transactions electronically. Timothy (2012), describes electronic banking as the use of internet as a remote channel for providing services such as opening a deposit account, transferring funds from one account to another and paying bills. This concept implies that through the internet, bank customers can access different forms of bank products and services.

Ngango, Mbabazize and Shukla (2015) view e-banking as an umbrella term for the process by which various classes of customers may perform banking business electronically without necessarily visiting a brick and mortar institution. By this, it is meant that an individual customer can carry out financial transactions at the comfort of his house, office or even in transit.

The Central Bank of Nigeria (CBN) (2003), in its report of technical committee on electronic banking, views the term to cover both computer and telephone banking. In other words, the concept of e-banking is referred to as the use of ICT by banks to provide services and mange customer relationships more quickly and satisfactorily.

In another dimension, Edet (2008) opines that e-banking is a system by which transactions are performed electronically with the use of devices such as Automated Teller Machine (ATM), Point of Sale (POS) terminals, GSM phones and V-cards. She further stressed that e-banking is a form of bank transaction where people can transfer funds, make enquiry for account balance, pay bills and manage their assets such as stocks online. This definition majorly focuses on the type of devices through which customers can transact businesses as well as the type of services that can be delivered electronically by banks to their customers.

Therefore, while the literal meaning of electronic banking hinges on how banks and their customers may conduct their respective business transactions through various electronic devices, the concept of customer satisfaction dwells on the perceived ability of a product or service to meet the customer's expectation. According to Anderson and Srinivasan (2003) in Jham (2016), if the p0erceived performance of the product or service matches or even is beyond the customer's expectation, such a customer is said to be satisfied with the product and vice versa. In other words customer satisfaction revolves around the state of mind that the customer has about a particular product. Therefore, customer satisfaction plays an important role in consumer buying behavior because a satisfied customer may repeat purchase which may eventually lead to customer retention or loyalty. It is as a result of this that service providers or marketers in general often handle customers in such a way that they can be satisfied with their services or product.

\subsection{Empirical Review}

Worku, Tilahun and Tafa (2016), studied the impact of e-banking on customers' satisfaction in Ethiopian banking industry using 402 customers of 2 commercial banks in Gondar city of Ethiopia. The study used chi-square $\left(x^{2}\right)$, t-test and regression analysis in its data analysis where it was reported that there is a strong and positive relationship between e-banking and customer satisfaction. In other words, e-banking has positively improved customers' satisfaction with bank products and services in Ethiopia.

In a study of customers' perception and satisfaction towards electronic banking in Khammam district by Reddy and Reddy (2015), it was disclosed that about $70 \%$ of the respondents exhibited positive perception and are satisfied with e-banking services. They used 200 respondents and Anova was employed in the data analysis.

In Nigeria, Babatunde and Salawudeen (2017) conducted an analysis of electronic banking and customer satisfaction using 40 customers of Access bank as a sample. Descriptive and Chi-Square test were used to analyse the data. It was revealed that a positive relationship exists between e-banking and customers' satisfaction because according to them, e-banking system has made banking transactions easier.

In a related study by Asiyanbi and Isola (2018) on e-banking services' impact and customers' satisfaction in selected bank branches in Ibadan Metropolis, Oyo State, Nigeria, it was reported that customers are satisfied with e-banking due to its cashless nature, cash accessibility, time saving from bank visitations and seamless transactions. They used 100 bank customers in bank branches located in Challenge, Dugbe, Agbeni, Gbogi, Ojoo and Secretariat districts in Ibadan metropolis as sample. Pearson correlation and T-test were utilized in their data analysis.

\section{Research Methodology}

The study covered bank customers in the six states of the North-Eastern region of Nigeria namely, Adamawa, Bauchi, Borno, Gombe, Taraba and Yobe. A total of four hundred and fifty (450) customers from three (3) selected banks across the region were used as respondents. That is, 450 customers of Union Bank of Nigeria (UBN), Guaranty Trust Bank (GTB) and First Bank of Nigeria (FBN) were used as sample. In other words, 25 respondents from each of the 3 banks in a state, (making 75 from each state) and also a adding up to a total of 450 respondents formed the sample.

The study adopted a purposes non-probability sampling technique in selecting the sample. The purposive sampling method was utilized in order to avoid selecting customers who might not be users of e-banking system. 
Questionnaires and personal interview were used to gather the data. The questionnaires were administered in the state capitals by the researcher with the help of research assistants chosen from the respective states. Administration of questionnaires was deliberately restricted to the state capitals because it was felt that all the selected banks have branches in the state capitals and most customers are concentrated in the state capitals largely due to the insurgency affecting the North-East. The questionnaire was designed using three (3) points Likert scale where $1=$ Not satisfied, 2 = Moderately satisfied and $3=$ Satisfied.

In situations where respondents were discovered to be unable to read and write, the questions in the questionnaire were read and interpreted to them while their responses were noted thereby transforming the method of data collection into personal interview. The data collected were analysed using descriptive statistics and ChiSquare tests. That is, while descriptive Statistics was used to analyse the data on sample frame as well as customers' reaction to their levels of satisfaction with e-banking system, Chi-Square tests were employed to test the hypothesis.

\section{Data Presentation and Analysis}

4.1. Data Presentation

Table 1: Number of questionnaires administered and retrieved according to Bank and State.

\begin{tabular}{|c|llllll|c|}
\hline \multicolumn{1}{|c}{ Banks } & \multicolumn{7}{c|}{ State } \\
\cline { 2 - 8 } & Adamawa & Bauchi & Borno & Gombe & Taraba & Yobe & Total \\
Union Bank of Nigeria (UBN) & & & & & & & \\
Guaranty Trust Bank (GTB) & 25 & 25 & 25 & 25 & 25 & 25 & 150 \\
First Bank of Nigeria (FBN) & 25 & 25 & 25 & 25 & 25 & 25 & 150 \\
Total & 25 & 25 & 25 & 25 & 25 & 25 & 150 \\
\cline { 2 - 9 } & 75 & 75 & 75 & 75 & 75 & 75 & 450 \\
\hline
\end{tabular}

Note: All questionnaire and administered were properly filled and retrieved.

\subsection{Data Analysis and Results}

Table 2: Distribution of Respondents by levels of Satisfaction with e-banking.

\begin{tabular}{|l|lll|l|}
\hline \multicolumn{5}{|c|}{ Levels of Satisfaction } \\
\hline E-Banking System & 1 = Not satisfied & $\mathbf{2}=$ Moderately Satisfied & 3 = Satisfied & Total \\
Transaction Time & $170(38)$ & $130(29)$ & $150(33)$ & $450(100)$ \\
Transaction Cost & $98(22)$ & $105(23)$ & $247(55)$ & $450(100)$ \\
Reliability & $115(26)$ & $218(48)$ & $117(26)$ & $450(100)$ \\
Ease of use & $55(12)$ & $145(32)$ & $250(56)$ & $450(100)$ \\
Convenience & $55(12)$ & $175(39)$ & $220(49)$ & $450(100)$ \\
Security/Privacy & $205(46)$ & $119(26)$ & $126(28)$ & $450(100)$ \\
\hline
\end{tabular}

Note: The figures outside parenthesis are frequencies while those inside the parenthesis are percentages.

Table 2 depicts respondents' distribution according to their responses to their levels of satisfaction with ebanking system. Their levels of satisfaction are expressed in terms of not satisfied, moderately satisfied and satisfied. The result of the analysis indicate that majority of them, accounting for $38 \%$ are not satisfied with transaction time, while $33 \%$ are satisfied leaving only $29 \%$ of them that are moderately satisfied. On the issue of transaction cost, most of them, represented by $55 \%$ are satisfied $23 \%$ are moderately satisfied while only $22 \%$ are not satisfied.

However, the results also revealed that most of the respondents, measuring $48 \%$ are moderately satisfied with reliability of e-banking system, while $26 \%$ and another $26 \%$ of them are satisfied and not satisfied respectively. Ease of use is also one of the features of e-banking where majority of them accounting for $56 \%$ are satisfied with it, and $32 \%$ are moderately satisfied and only $22 \%$ of them indicating dissatisfaction. On the issue of convenience, again, most of them numbering about $49 \%$ are satisfied, and $39 \%$ are also moderately satisfied and only $12 \%$ are totally not satisfied. Finally, the result reported that most of the customers accounting for $46 \%$ are not satisfied with the security/privacy of the system, while $28 \%$ are said to be satisfied thereby leaving only $26 \%$ as moderately satisfied.

\section{Testing of Hypothesis}

Ho: Customers' Satisfaction with e-banking system in the North-Eastern Region of Nigeria is not statistically significant.

\section{Bench Marks Using Population/Sample Mean}

Note: The study data was collected using 3points Likert Scale $1=$ Not satisfied, $2=$ Moderately satisfied, $3=$ Satisfied. It's erroneous to add the entries of ' 2 ' to either side of the satisfaction scaling. Thus, the resultant data was calibrated into a categorical data using Bootstrap Specification and Population Mean as Bench Mark (See tables $3-5$ ).

Justification: The study adopted the 'sample mean' as the decision benchmark to discriminate the actual opinions 
of the respondents. This is consistent with Onwe (1998) and Momoh (2017), who observe that researchers can be 99 percent confident that the true value of a population mean will be within 10 percent of the sample mean. Afolayan (2009) also argues that for a population that is normally distributed, 95 percent of the sample mean will lie within the limits of two standard errors $(\mu \pm 2 \sigma / \sqrt{\eta})$ on either side of the true or false of the population mean.

Table 3: Bootstrap Specifications

\begin{tabular}{|l|lr}
\hline Sampling Method & Simple & 1000 \\
Number of Samples & & $95.0 \%$ \\
Confidence Interval Level & & \\
Confidence Interval Type & Percentile & \\
\hline
\end{tabular}

Source: Field Survey

Table 4: Descriptive Statistics (Population Mean)

\begin{tabular}{|c|c|c|c|c|c|c|}
\hline & & \multirow[t]{3}{*}{ Statistic } & \multicolumn{4}{|c|}{ Bootstrap $^{a}$} \\
\hline & & & \multirow[t]{2}{*}{ Bias } & \multirow[t]{2}{*}{ Std. Error } & \multicolumn{2}{|c|}{ 95\% Confidence Interval } \\
\hline & & & & & Lower & Upper \\
\hline \multirow{6}{*}{ Customers' satisfaction } & $\mathrm{N}$ & 450 & 0 & 0 & 450 & 450 \\
\hline & Range & 12.00 & & & & \\
\hline & Minimum & 6.00 & & & & \\
\hline & Maximum & 18.00 & & & & \\
\hline & Sum & 5812.00 & & & & \\
\hline & Mean & 12.9156 & .0005 & .2052 & 12.5111 & 13.3533 \\
\hline Valid N (listwise) & $\mathrm{N}$ & 450 & 0 & 0 & 450 & 450 \\
\hline
\end{tabular}

Source: Field Survey

Table 5: Descriptive Statistics (Individual Sample Means)

\begin{tabular}{|l|r|r|r|r|r|r|c|}
\hline $\begin{array}{l}\text { e-banking satisfaction } \\
\text { Proxies }\end{array}$ & $\mathrm{N}$ & Range & Minimum & Maximum & Sum & Mean & $\begin{array}{c}\text { Std. } \\
\text { Deviation }\end{array}$ \\
\hline Transaction Time & 450 & 2.00 & 1.00 & 3.00 & 880.00 & 1.9556 & .84304 \\
Transaction Cost & 450 & 2.00 & 1.00 & 3.00 & 1049.00 & 2.3311 & .81148 \\
Reliability & 450 & 2.00 & 1.00 & 3.00 & 902.00 & 2.0044 & .71881 \\
Ease of Use & 450 & 2.00 & 1.00 & 3.00 & 1095.00 & 2.4333 & .70078 \\
Convenience & 450 & 2.00 & 1.00 & 3.00 & 1065.00 & 2.3667 & .69118 \\
Security/Privacy & 450 & 2.00 & 1.00 & 3.00 & 821.00 & 1.8244 & .84042 \\
Valid N (listwise) & 450 & & & & & & \\
\hline
\end{tabular}

\section{Source: Field Survey}

Hence, the categorical data is subject to multiple statistical examinations using Cross-tabulation, 'ChiSquare' and 'Eta Effect Value'. More so, Post-hoc (sensitivity) tests were conducted with the use of 'Contingency Coefficient', 'Kendall's tau-c' and 'Pearson's R Correlation' (see tables 6 - 9 respectively).

Table 6: Computed Customers' Satisfaction * e-Banking (Crosstab)

\begin{tabular}{|c|c|c|c|c|}
\hline \multirow[t]{2}{*}{ Count } & & \multicolumn{2}{|l|}{ e-banking } & \multirow[t]{2}{*}{ Total } \\
\hline & & Not Satisfied & Satisfied & \\
\hline Computed & Customers' Not Satisfied & 115 & 0 & 115 \\
\hline Satisfaction & Satisfied & 55 & 280 & 335 \\
\hline Total & & 170 & 280 & 450 \\
\hline
\end{tabular}

Source: Field Survey

The statistics fashioned Two-sides of a Coin Analysis; whereas on one side is the customers' satisfaction and on the other hand is the e-banking performance (operations) judging from purview of the same observable proxies (TT Transaction Time; TC $\sim$ Transaction Cost; RE Reliability; EU Ease of Use; CO $\sim$ Convenience \& SP Security/Privacy. 
Table 7: Chi-Square Tests (2 tails-test)

\begin{tabular}{|c|c|c|c|c|c|c|}
\hline & TT & $\mathrm{TC}$ & RE & EU & $\mathrm{CO}$ & SP \\
\hline Pearson Chi-Square & $254.434^{\mathrm{a}}$ & $364.958^{\mathrm{a}}$ & $450.000^{\mathrm{a}}$ & $182.526^{\mathrm{a}}$ & $182.526^{\mathrm{a}}$ & $184.620^{\mathrm{a}}$ \\
\hline Continuity Correction ${ }^{b}$ & 250.890 & 359.973 & 444.759 & 178.095 & 178.095 & 181.683 \\
\hline Likelihood Ratio & 297.491 & 375.321 & 511.521 & 174.990 & 174.990 & 230.387 \\
\hline Linear-by-Linear Association & 253.868 & 364.147 & 449.000 & 182.121 & 182.121 & 184.209 \\
\hline $\mathrm{N}$ of Valid Cases & 450 & 450 & 450 & 450 & 450 & 450 \\
\hline
\end{tabular}

$\boldsymbol{D} \boldsymbol{f}=1$ Asymp. Sig. (2-sided) $<\mathbf{0 . 0 0 5}$ (for all the proxies measurement)

a. 0 cells $(0.0 \%)$ have expected count less than 5. The minimum expected count is 43.44 .

b. Computed only for a $2 \times 2$ table

Source: Field Survey

Table 8: Directional Measures Using Eta Effect Value

\begin{tabular}{|lll|r|r|r|r|r|r|}
\hline & & TT & TC & RE & EU & CO & SP \\
\hline $\begin{array}{l}\text { Nominal by } \\
\text { Interval }\end{array}$ & $\begin{array}{l}\text { Computed Customers' } \\
\text { (Independent) } \\
\text { e-banking (Dependent) }\end{array}$ & .752 & .901 & 1.000 & .637 & .637 & .641 \\
& .752 & .901 & 1.000 & .637 & .637 & .641 \\
\hline
\end{tabular}

Source: Field Survey

Note: TC \& RE yields extremely huge effects due to high degree of correlation (see Table 9).

Table 9: Symmetric Measures (Post-hoc tests)

\begin{tabular}{|c|c|c|c|c|c|c|c|}
\hline & & TT & $\mathrm{TC}$ & RE & $\mathrm{CO}$ & EU & SP \\
\hline Nominal by Nominal & $\begin{array}{l}\text { Contingency } \\
\text { Coefficient }\end{array}$ & .601 & .669 & .707 & .537 & .537 & .539 \\
\hline Ordinal by Ordinal & Kendall's tau-c & .636 & .648 & .761 & .364 & .364 & .557 \\
\hline Interval by Interval & $\begin{array}{ll}\text { Pearson's } & \mathrm{R} \\
\text { Correlation } & \end{array}$ & .752 & .901 & 1.000 & .637 & .637 & .641 \\
\hline $\mathrm{N}$ of Valid Cases & & 450 & 450 & 450 & 450 & 450 & 450 \\
\hline & Approx. Sig. & .000 & .000 & .000 & .000 & .000 & .000 \\
\hline
\end{tabular}

$a$. Not assuming the null hypothesis. $b$. Using the asymptotic standard error assuming the null hypothesis. c. Based on normal approximation.

Source: Field Survey

Observation: it is apparent that CO \& EU proxies reported the same results from Tables 7 - 9. It isn't a computational error but consequential approximation earlier reported during data calibration (see their sample means in Table 5).

Tables $3-9$ sought to test whether or not customers' satisfaction with e-banking system is statistically significant. The statistical results revealed that customers' satisfaction with e-banking satisfaction proxies. Thus, these statistical results indicate that customers' satisfaction with e-banking system is strong, positive and statistically significant. This is affirmed by the r-values of $0.752,0.901,1.000,0.637,0.637$ and 0.641 for transaction time, transaction cost, reliability, ease of use, convenience and security/privacy respectively as well as the p-values of 0.000 for all the e-banking satisfaction proxies. Thus, these statistical results indicate that customers' satisfaction with e-banking system in the North-Eastern region of Nigeria is statistically significant at $5 \%$, and even $1 \%$ levels of significance.

\subsection{Discussion of Results}

The results of the study established that customers' satisfaction with e-banking system in the North-Eastern part of Nigeria is strong, positive and statistically significant. This agrees with the findings of Worku, Tilahun and Tafa (2016) who studied the impact of e-banking and customers' satisfaction in Ethiopian banking industry where they used 402 customers of 2 commercial banks. They used Chi-Square test, t-test, and regression analysis in testing their data which reported that there is a strong, and positive relationship between e-banking and customer satisfaction.

The results also corroborate Reddy and Reddy (2015) who investigated customers' perception and satisfaction towards e-banking in Khammam District in India where they used Anova to test their data. They disclosed that $70 \%$ of the respondents exhibited positive perception and were said to be satisfied with e-banking services.

Similarly, the results confirm the findings of Babatunde and Salawudeen (2017) who conducted an analysis of electronic banking and customer satisfaction in Nigeria using 40 customers of Access bank. Their study utilized descriptive statistics and Chi-Square test in analyzing the data where it was shown that a positive relationship 
exists between e-banking and customers' satisfaction. This is according to them, e-banking system has made banking transactions easier and customers are satisfied with the system.

Finally, the results affirm the findings of Asiyanbi and Isola (2018) on e-banking services' impact on customers' satisfaction in selected bank branches in Ibadan Metropolis, of Oyo State in Nigeria. They used one hundred (100) bank customers as sample, and Pearson Correlation to test the data where they reported that customers are satisfied with e-banking due to its cashless nature, cash accessibility, time saving from bank visitations and seamless transactions.

\section{Conclusion/Suggestion}

The study revealed that customers are generally satisfied with e-banking system in North-Eastern Nigeria. However, the strength of the satisfaction vary among the e-banking satisfaction proxies especially while the customers exhibited very strong satisfaction for transaction cost, transaction time, and reliability, convenience, ease of use, and security/privacy recorded lower strength of satisfaction. The paper therefore, suggests that commercial banks should improve on the ease of use, convenience, and security/privacy of the e-banking system. If this measure is taken into consideration, customers' satisfaction with the system might be enhanced.

\section{References}

Afolayan, J. A. (2009). Hospital Information System. National Open University of Nigeria, NOUN, Lagos; Nigeria. Akingbola, E. (2006). The New Face of Banking in Nigeria: Lessons and Challenges. The Nigerian Banker, April - June.

Anderson, R. E. \& Srinivasan, S. S. (2003), in Jham, V. (2016). Customer Satisfaction with Internet Banking: Exploring the Mediating Role of Trust. Journal of Emerging Trends in Economics and Management Sciences, UAE, 7(2).

Asiyanbi, H. B. \& Isola, A. A. (2018). E-banking Services Impact and Customers Satisfaction in selected Bank Branches in Ibadan Metropolis, Oyo State, Nigeria. Growing Science Journal of Accounting, 4(1).

Babatunde, M. O. \& Salawudeen, M. O. (2017). Analysis of Impact of Electronic Banking on Customers' Satisfaction in Nigeria. Greener Journal of Business and Management Studies, 7 (3).

Central Bank of Nigeria, CBN, (2003). Report of Technical Committee on E-banking, Abuja, Nigeria.

Edet, O. (2008). Electronic Banking and its Effect in Banking Industry. International Journal of Investments and Finance, 21 (1).

Idowu, A. A. (2005). Automated Banking and the Nigerian Economy. Journal of Internet Banking and Commerce, 10 (1).

Momoh, M. (2017). Management Information System, MIS Capacity and Effective Information Management in Nigerian Universities: An Empirical Investigation of Northern Nigeria - Germany, Lambert Academic Publishing (Scholars' Press).

Ngango, A; Mbabazize, M. \& Shukla, J. (2015). E-banking and Performance of Commercial Banks in Rwanda. European Journal of Accounting, Auditing and Financial Research, 3 (1).

Onwe, O.J. (1998). Elements of Project Dissertation Writing: A guide to Effective Dissertation Report Impressed Publishers, Lagos, Nigeria.

Reddy, D. N. V. K. \& Reddy, M. S. (2015). A Study on Customers' Perception and Satisfaction Towards Electronic Banking in Khammam District of Telangana in India. Journal of Business and Management, 17(12).

Simon, V. T. \& Thomas A. S. R. (2016). Effect of Electronic Banking on Customers Satisfaction in selected Commercial Banks in Kenya. International Academic Journal of Human Resource and Business Administration, 2(2).

Timothy, A.T. (2012). Electronic Banking Services and Customer Satisfaction in the Nigerian Banking Industry. International Journal of Business Management, 2(3).

WorKu, G; Tilahun, A. \& Tafa, M.A. (2016). The Impact of e-banking on Customers' Satisfaction in Ethiopian Banking Industry (The Case of Customers of Dashen and Wogagen Banks in Gondar city. Journal of Business and Financial Affairs, 5(2). 